\title{
Chivo expiatorio-mártir, héroe nacional y suicida-bomba: las metamorfosis sin fin de la violencia colectiva
}

\author{
Josetxo Beriain \\ Universidad Pública de Navarra \\ Departamento de Sociología \\ josetxo@unavarra.es
}

\section{Resumen}

Este trabajo analiza tres tipos sociales —el chivo expiatorio, el héroe nacional y el suicida bomba-que históricamente encarnan a la violencia, sus contextos sociales, los motivos que les mueven y los tipos de acción que desencadenan, teniendo siempre en cuenta que existen otros tipos sociales - el ciudadano, la celebridad en la cultura moderna- que contraactúan en pos del orden pacíficamente, intentando poner cerco a la violencia desatada por los tipos anteriores encarnados.

Palabras clave: violencia, chivo expiatorio, mártir, héroe nacional, suicida bomba, ciudadano, víctima, asesino.

Abstract. Buck Emisaire-Martyr, National Hero and Suicide-Bomber: The Endless Metamorphosis of Collective Violence

This paper takes into account the sociological profiles of three social types - the scapegoat-martyr, the national hero and the suicide-bomber- who historically embody violence in its specific social environments and with the respective motives which are behind their actions, being aware always that those types are being counteracted in a peaceful way by another social types such as the citizen, the celebrity of the modern culture and so on.

Key words: violence, scapegoat, martyr, national hero, suicide-bomber, citizen, celebrity, victim, assassin.

\section{Sumario}

\section{Introducción}

1. La primera metamorfosis: del ensalzamiento del «asesino» al ensalzamiento de la "víctima» como mártir
2. La segunda metamorfosis: el «mártir» que se convierte en "héroe nacional»

3. La tercera metamorfosis: entre la cultura de la celebridad y el suicida bomba

A modo de conclusión 


\section{Introducción}

Este trabajo plantea la hipótesis de que, en la historia de las sociedades, existen tipos sociales contrapuestos que, por una parte, encarnan a la violencia colectiva y tipos sociales cuya función es, por otra parte, luchar contra la violencia, aunque no consigan erradicarla totalmente, de una vez por todas. La violencia colectiva es como ese extraño familiar que fatídicamente retorna, es como ese eterno retorno de un viejo conocido que, llamado o no llamado, siempre ha estado "co-presente» en nuestras vidas y en nuestras sociedades, de una o de otra manera. En estas páginas, pretendo dar cuenta de cuáles son las principales figuras en las que se encarna la violencia, así como de aquellas contrafiguras que "exorcizan", que ponen cerco a la violencia y a sus portadores sociales más significativos. En primer lugar, analizaré la contraposición existente en las sociedades arcaicas entre el chivo expiatorio - aquél que aleatoriamente es elegido como sacrificable, como "falso culpable» al que se le endosan los males de la comunidad y que, por tanto, debe ser sacrificado para que la comunidad recupere su normalidad- y el mártir en sus diversas manifestaciones, tanto abrahámicas como postabrahámicas. En segundo lugar, y como transformación de la anterior contraposición, analizaré el fermento de violencia que anida en el «héroe nacional» que forja la nación moderna a finales del siglo XIX, contrapesado por la acción decididamente pacífica del ciudadano. En tercer lugar, aunque a simple vista pareciera que aquí acaba nuestra descripción sociológica de los tipos ideales de la violencia, un análisis un poco más atento de la realidad social actual, presente en la mayor parte de sociedades, pone de manifiesto la mutación de un nuevo tercer tipo encarnado en el terrorista nihilista, movido no tanto por el miedo a Dios o el miedo al Estado, sino por algo más impredecible, el miedo a la nada, la ausencia de fundamento. Frente al frenesí nihilista de este tipo de violencia, se dibuja un contramodelo pacífico en la cultura de la celebridad, que da popularidad, fama y reconocimiento a personas que han realizado contribuciones sociales en distintos ámbitos de la cultura. Para la realización de estos supuestos, me serviré del análisis de trabajos procedentes de la antropología simbólica, la sociología y la ciencia política.

\section{La primera metamorfosis: del ensalzamiento del «asesino» al ensalzamiento de la "víctima» como mártir}

Todos nosotros andábamos errantes como ovejas y cada uno marchó por su camino, y Yahvé descargó sobre él la culpa de todos nosotros.

(Is. 53,6)

Misericordia quiero, que no sacrificio.

(Jesús de Nazareth, en Mt. 9,13) 
La violencia dentro de las especies existe ya entre los animales, de forma inequívoca en las rivalidades de tipo sexual, pero permanece aminorada. El vencedor perdona al vencido y así es como se establecen las relaciones que desempeñan un papel determinante en la vida animal. Éstas son relaciones de dominación. Los seres humanos somos más violentos que los animales, puesto que nos matamos entre nosotros. A esto llamamos agresión. El problema con esta noción es su unilateralidad, ya que divide a la humanidad entre agresores y agredidos, autoincluyéndonos todos nosotros en la segunda categoría y olvidando que los conflictos humanos implican a ambos lados en una suerte de reciprocidad ambivalente. En realidad, dice René Girad, «somos competitivos más que agresivos» ${ }^{1}$. Además de los apetitos que compartimos con los animales, tenemos un anhelo más problemático para el que no hay ninguna correspondencia institucional, el deseo. Literalmente, no sabemos qué desear y, en orden a encontrar ese objeto del deseo, miramos a la gente que admiramos: imitamos sus deseos. Ambos, modelos e imitadores del mismo deseo, inevitablemente desean el mismo objeto y se convierten en rivales. A diferencia de las rivalidades entre animales, estas rivalidades imitativas o miméticas pueden hacerse tan intensas y contagiosas que no sólo pueden conducir al asesinato, sino que se extienden peligrosamente por toda la comunidad. René Girard, en Mensonge romantique et verité romanesque (1961), afirma que el deseo no está enraizado en el objeto, ni en el sujeto, sino en la apropiación deliberada de unos sujetos de los objetos de otros. En una serie de lecturas sobre cinco grandes novelistas europeos (Cervantes, Stendhal, Flaubert, Dostoievski y Proust), Girard descubre la naturaleza mimética (imitativa) del deseo, en contraste con la creencia romántica de que el deseo es originario. En La violencia y lo sagra$d o(1972)^{2}$ generaliza su teoría del deseo al nivel del orden cultural. La pregunta que se hace Girard es: «¿Cuál es la función de la religión en el nivel de las relaciones humanas?». Asumiendo las teorías de Frazer, Mauss y Lévi-Strauss, Girard sugiere que la religión tiene la función de mantener la violencia fuera de la comunidad, de trascendentalizarla, de hacerla sagrada. Si con Durkheim veíamos que lo sagrado se identificaba con lo social como tal, ahora vemos que lo sagrado es la violencia eficazmente retraída de la comunicación humana, ya que lo religioso dice realmente a los hombres lo que hay que hacer y no hacer para evitar el retorno de la violencia destructora, y la violencia es lo sagrado desviado de su posición divina ${ }^{3}$ creando el desorden en la ciudad. En El misterio de nuestro mundo ${ }^{4}$, Girard, tomando como base una interpretación no

1. R. Girard, "Violence and Religion: Cause or effect?», The Hedgehog Review, primavera, 2004, vol. 6, 1, p. 9.

2. R. GIRARD, La violence et le sacré, París, 1972 (en adelante, cito de la traducción española, La violencia y lo sagrado, Barcelona, 1983, abreviadamente VS).

3. G. Scholem, «El Bien y el Mal en la Cábala», en: A. Ortiz-Osés (ed.), Círculo Eranos, I, Barcelona, 1994, p. 100.

4. R. GIRARD, Des choses caches depuis la fondation du monde, París, 1978 (en adelante, cito la traducción española, El misterio de nuestro mundo, Salamanca, 1982, abreviadamente $M N M$ ). 
sacrificial de la Biblia, muestra a Cristo como la primera víctima inocente que hace visible por primera vez la arbitrariedad de las víctimas de la conducta sacrificial primitiva, mostrando una posible sutura simbólica (muerte de Cristo) a la fisura (herida) real del mundo (el mal, la violencia entendida como sufrimiento padecido injustamente $)^{5}$.

\section{El fenómeno de la crisis sacrificial y el nacimiento del chivo expiatorio como "primer mártir» 0 "protomártir»}

Antes de ofrecer las ejemplificaciones sobre la crisis sacrificial en las adaptaciones trágicas de los mitos griegos, en las mitologías primitivas y en los estudios de Freud, Lévi-Strauss y P. L. Berger, que sirven de base empírica a la delimitación de la violencia originaria, voy a abordar las cuestiones preliminares relativas al significado y a la función del sacrificio ritual.

El sacrificio, como han puesto de manifiesto Hubert y Mauss, consiste en "establecer un medio de comunicación entre los mundos sagrado y profano a través de la mediación de una víctima, es decir, de una cosa que es destruida en el transcurso de una ceremonia ${ }^{6}$. Si la muerte del objeto de sacrificio supone que el ejecutor se ha sacralizado al tomar contacto con los dominios de la divinidad, a su vez se ha podido deshacer, a través de la víctima, de su propia crisis. Afirman Hubert y Mauss que «es criminal matar a la víctima porque es sagrada [...], pero, la víctima no sería sagrada si no se la matara» ${ }^{7}$. La sociedad, en clave religiosa, despliega formas sociales violentas para aminorar otras formas asociales «más» violentas. La religión es la primera «maquinaría social» destinada a exorcizar a la violencia a través del uso de la violencia inherente al ritual sacrificial. Thomas Mann, de forma contundente e inapelable, recoge esta idea al afirmar que la cultura no es sino «la devota y ordenadora, por no decir benéfica, incorporación de lo monstruoso y de lo sombrío en el culto de lo divino» ${ }^{8}$. Sin duda, hay una ambivalencia entre lo sagrado y el uso de la violencia (profanamente manifestada, como mezcla, desorden, impureza) ${ }^{9}$. La crisis sacrificial debe ser definida como una crisis de diferencias, ya que son las distinciones diferenciales las que proporcionan a los individuos su «identidad» y les permiten a unos situarse en relación con los otros. $\mathrm{El}$ «yo» se entiende en relación con el «tu». La diferencia entre ambos constituye la identidad de ambos. La diferencia, articulada en forma de distinciones socioculturales de rango, de riqueza, de edad, es el principio de todo orden cultural, como ha apuntado Niklas Luhmann. Toda

5. A. ORTIZ-OsÉs, Las claves simbólicas de nuestra cultura, Barcelona, 1993. Sobre el mal como sufrimiento padecido, no como puro accidente ontológico, véase el trabajo de E. LEVINAS, «Useless Suffering», en: R. Bernasconi y D. Word (eds.), The Provocation of Levinas: Rethinking the Other, Nueva York, 1988, p. 161-162.

6. Hubert y Mauss, Sacrifice, Chicago, 1981, p. 97.

7. Hubert y Mauss, op. cit., p. 29.

8. Th. Mann, Doktor Faustus, Barcelona, 1978, p. 15.

9. M. Douglas, Purity and Danger, Londres, 1966. 
disolución de la estructura de roles familiar (el caso de Edipo) o social (Dionysos, los reyes en los mitos africanos, etc.) originan la rivalidad y la violencia, se produce una disolución de las estructuras, una desdiferenciación que origina la violencia recíproca, cuyo arquetipo representan Caín y Abel. Para evitar la violencia recíproca de "todos contra todos», la "comunidad vuelve a sentirse solidaria a costa de una víctima no sólo incapaz de defenderse, sino totalmente incapaz de suscitar la venganza; su muerte no podrá provocar nuevas agitaciones y hará que se supere la crisis, ya que une a todo el mundo contra ella» ${ }^{10}$. El «todos contra todos» ${ }^{11}$, en donde dos o más individuos pugnan por un mismo objeto del deseo - mujeres, armas, joyas, bienes escasos- del que todos quieren apropiarse, da paso al "todos contra uno", el chivo expiatorio, en donde se produce un transfert colectivo ${ }^{12}$ en el que la comunidad adquiere el control conjunto de los recursos necesarios para la acción guiada por una mímesis irracional violenta ${ }^{13}$. El paroxismo de la lucha fratricida da paso a la reconciliación de la comunidad a través del sacrificio de la víctima expiatoria en torno a la que se coaligan miméticamente todos. C. Lévi-Strauss describe, en El totemismo en la actualidad ${ }^{14}$, dos mitos que pertenecen a sociedades muy distantes la una de la otra, la de los indios ojibwa, en el norte de los Grandes Lagos norteamericanos, y la de los tikopia, en el oceano Pacífico, asimismo, T. Koch-Grünberg ${ }^{15}$ describe otro mito de los indios yahuna del noroeste del Brasil. P. L. Berger describe como la Gran Pirámide de Cholula, el Auschwitz mesoamericano, cercana a Puebla en México, nos recuerda que «si los dioses no fueran alimentados regularmente con sangre humana, el universo se destruiría» ${ }^{16}$. En los cuatro mitos se pone de manifiesto un proceso de ritualización sacrificial que es vivido dramáticamente en el sentido postulado por la tragedia griega. En la codificación religiosa de todos estos mitos se pone de manifiesto que:

1. La crisis mimética se produce siempre.

2. La unión de todos contra una víctima única es la resolución normal en el plano cultural y la resolución propiamente normativa, ya que de ella es de donde brotan todas las reglas culturales ${ }^{17}$.

3. Los mitos surgen de las crisis sacrificiales, de las que son una transfiguración retrospectiva, una relectura a la luz del orden cultural surgido de la crisis,

10. R. GIRARD, $M N M$, p. 36.

11. Hobbes, en el Leviatán, partirá de este mismo punto de vista, hay una «guerra de todos contra todos», para llegar a la conclusión de que hace falta una instancia externa, la comunidad, que tome cartas en el asunto, ya no recurriendo al sacrificio de un inocente, sino a la vigilancia del orden y en caso de infracción del orden interviene alguien investido de prerrogativas para hacer uso de la violencia, el Estado soberano.

12. R. GIRARD, $V S$, p. 15.

13. S. Moscovici, La Era de las multitudes, México, 1985, p. 339 y s.

14. C. LÉvi-STrauss, El totemismo en la actualidad, México, 1965, p. 34-35, 43-44.

15. T. KoCH-GrünBERG, Zwei Jahren unter der Inianen. Reisen in Nord-West Brasilien, Berlín, 1903-1905, 1910, p. 292-293.

16. P. L. BerGer, Pirámides de sacrificio, Santander, 1979, p. 17 y s.

17. R. GIRARD, $M N M, 1982$, p. 39. 
proporcionando una «cura sutura» a la «herida fisura» de la violencia sacrificial. Los mitos comienzan con una crisis mimética y concluyen con el mismo tipo de drama: una víctima es asesinada por toda la comunidad y es finalmente divinizada. Todas las culturas arcaicas solemnemente inmolan a víctimas con la esperanza de prevenir conflictos miméticos.

A modo de ejemplificación de la crisis, siguiendo a Girard, vamos a considerar Edipo Rey de Sófocles como locus del mito. El conflicto trágico que subyace en Edipo Rey es un juego entre identidad y diferencia consideradas como los dos «reflejos» que ofrece el espejo de la sociedad a la manera de una copresencia simultánea de transparencia y opacidad. Edipo es regicida en el orden de la polis y es parricida en el orden familiar, al matar a su rey y padre Layo, además de romper con la interdicción cultural del incesto; al acceder sexualmente a Yocasta, rompe con la premisa: «Sé como tu padre», «imítalo en todo, excepto en el acceso sexual a su esposa» (tu reina y madre). En los términos de Bateson en Pasos hacia ecología de la mente (1972), Edipo se enfrenta a un double bind, a un doble imperativo contradictorio: imitame / no me imites; sé asi (como tu padre) / no seas asi (como tu padre en su relación con su esposa, tu madre). Y esto es lo que constituye propiamente la producción del orden cultural sobre el caos natural. Lévi-Strauss, en Las estructuras elementales del parentesco (1949), ofrece una interpretación del porqué de ese doble vínculo. Según él, la exogamia tiene un valor menos negativo que positivo, ya que afirma la existencia social del otro, y sólo prohíbe el matrimonio endogámico (Edipo-Yocasta), no porque tal matrimonio constituya un peligro biológico, sino porque del matrimonio exogámico resulta un beneficio social: la comunicación y el intercambio de bienes, mensajes y mujeres. Edipo, como Ulises en La Odisea de Homero, es la víctima de un destino que ignora. Su tiempo cuantitativo determinado en torno al esquematismo antes/después, no da cuenta de un tiempo cualitativo indeterminado ${ }^{18}$, recurrente y revocable que alberga el sentido de las causas y consecuencias no intencionales de la acción racional ${ }^{19}$ de estos héroes míticos. «Cada cual, al comienzo, se cree capaz de dominar a la violencia, pero es la violencia la que domina sucesivamente a todos los protagonistas, metiéndoles a pesar suyo en un juego, el de la reciprocidad violenta, al cual siempre creen poder escapar por el hecho de que toman por permanente y esencial una exterioridad accidental y temporal $»^{20}$. Ese mismo destino se pone de manifiesto en la famosa traducción que Heidegger hace del fragmento de Anaximandro cuando escribe: «Ahora bien, a partir de donde hay generación de las cosas, allí se produce también la destrucción, según la necesidad; en efecto, pues tienen que pagar la culpa unas a otras y reparar la injusticia, según el ordenamiento del tiempo» ${ }^{21}$. Edipo, tras la

18. H. Corbin, «The Time of Eranos», en: J. Campbell (ed.), Man and Time: Papers from the Eranos Yearbook, Princeton, 1957, vol. 3, p. XIII-XX.

19. H. WIESENTHAL, «Rational Choice», Zeitschrift für Soziologie, núm. 6, 1987, p. 446.

20. R. GIRARD, $V S$, p. 77.

21. M. Heidegger, Caminos de bosque, Madrid, 1995, p. 290 y s. 
quiebra de las diferencias, es consciente de su tiempo destinal y afirma: «Confiaos, no temáis, pues estos males míos, nadie de los hombres puede sufrirlos más que yo». Edipo está asumiendo, roto el equilibrio cultural, el rol de víctima propiciatoria, depositaria del mal que existe en la comunidad. Edipo aparece como el katharma ${ }^{22}$, la impureza, lo sucio ${ }^{23}$, que, a través del pharmakon ${ }^{24}$, del veneno remedio de la violencia sacrificial, originará una katharsis, una exoneración de la mancha, del pecado, de la falta que aqueja a la comunidad ${ }^{25}$. El pensamiento religioso ve en la víctima propiciatoria a una criatura sobrenatural que siembra la violencia para recoger a continuación la paz, a la manera de un temible salvador que hace enfermar a los hombres para luego curarlos. El sacrificio está relacionado con el paso del ser vilipendiado de la humillación al poder, es lo que George Bataille llama "la creación a través de una pérdida» ${ }^{26}$.

Las bacantes de Eurípides constituye otra ejemplificación prototípica de la violencia. Las bacantes se presenta como una bacanal ritual. El poeta trágico describe la desaparición de las diferencias, Dionysos derriba las barreras entre los hombres, tanto las de la riqueza, como las del sexo, las de la edad, etc. En los coros, los ancianos se mezclan con los jóvenes, las mujeres están en pie de igualdad con los hombres. Dionysos como representante divino de la exaltación disloca el orden cultural y la primera víctima destinal de la violencia es Penteo. Éste es asesinado y destrozado por su madre, unida a sus acompañantes en un frenesí dionisiaco. La máscara disfraz que porta Penteo no le sirve para ocultarse ante el frenesí violento del ritual bacanal en el cual él es la víctima propiciatoria que traerá la paz.

Estos mitos presentan a las víctimas como culpables y a las multitudes que ejecutan el asesinato como inocentes, pero, quizás, reinterpretados desde hoy, suenan mucho más como ecos de la violencia de una muchedumbre contados por la propia muchedumbre. En muchos mitos, la gente parece aterrorizada por su víctima prospectiva, preocupada solamente por protegerse ella misma del monstruo aterrorizante. En realidad, la víctima parece estar en la situación del narrador perseguido en los salmos bíblicos, rodeado de multitudes enfervorecidas y expuesto a sus iras. Al final, la víctima individual siempre muere y la gente, que participa en su inmolación, sale indemne. En muchos casos, crímenes atribuidos a víctimas individuales no son sino acusaciones oportunistas rutinariamente presentadas para justificar hechos sacrificiales de multitudes enfervorecidas contra quien ellas sienten que deben asesinar. En muchos casos, las víctimas son discapacitados físicos: ciegos, cojos, tuertos, jorobados o lisiados. Estas discapacidades sugieren cómo las turbamultas realmente seleccionan a las víctimas. Los depredadores animales seleccionan presas visiblemente anormales porque

22. R. GiRARD, VS, p. 299.

23. M. DOUGLas, Purity and Danger, Londres, 1966.

24. R. Girard, VS, p. 309.

25. Sobre los simbolismos del mal, véase el trabajo de P. RICOEUR, «La simbólica del mal», en: Finitud y culpabilidad, Madrid, 1982, p. 167-312.

26. G. Bataille, Visions of Excess. Selected Writings 1927-1939, Minneapolis, 1985, p. 120. 
son más fáciles de reducir y atrapar, pues bien, algo similar ocurre en el mundo humano: individuos "visiblemente» discapacitados o estigmatizados atraen la atención de las turbamultas. Un signo recurrente en muchos de estos mitos es la presencia de héroes míticos definidos como «extranjeros». El extranjero es, como dice Simmel, aquél que está «físicamente próximo y culturalmente alejado», por tanto, un extranjero visitante podría producir un cierto pánico y ser atacado simplemente por el hecho de que su lenguaje y sus maneras difieren de los estándares locales. Según René Girad, «las turbamultas siempre asesinan con bona fide a un elemento perturbador. No fue el descubrimiento de algún criminal auténtico, como pretenden los mitos, lo que reconcilió a estas comunidades arcaicas, sino la ilusión de tal descubrimiento. Las comunidades miméticamente transfirieron todas sus hostilidades a una víctima individual y se reconciliaron sobre la base de tal ilusión resultante» ${ }^{27}$.

\section{La superación no violenta de la crisis sacrificial y el nacimiento del «último mártir». El ejemplo de Jesús de Nazareth}

En los mitos bíblicos también se pone de manifiesto la presencia de la violencia sacrificial asociada a lo sagrado. En el mito de Caín, uno de los hermanos mata al otro y así queda fundada la comunidad cainita (Gen, 4,1-24; 6, 1-7). En el Éxodo, es todo el pueblo elegido el que llega a identificarse con la víctima expiatoria frente a la sociedad egipcia. Moisés se presenta como la víctima expiatoria y con él toda la comunidad judía que le rodea. Podríamos hablar de una comunidad expiato$\mathrm{ria}^{28}$ que conmemora, de alguna manera, la desgracia, todo lo que es de mal augurio, todo lo que inspira sentimientos de angustia o temor necesita un piaculum ${ }^{29}$ (encarar una calamidad, recordarla y deplorarla). El profetismo representa una respuesta singular a una vasta crisis de la sociedad hebrea interpretada por los profetas como una crisis religiosa y cultural (crisis espiritual en los términos de Daniel Bell). En los Cantos del Siervo de Yahvé, la crisis espiritual de la sociedad hebrea es portadora del fenómeno de transferencia colectiva. En el «corazón de la máquina generadora de lo religioso ${ }^{30}$ subyace la violencia originaria. Así, en Isaías:

Todos nosotros andábamos errantes como ovejas cada uno marchó por su camino,

y Yahvé descargó sobre él

la culpa de todos nosotros.

(Is. 53,6)

27. R. GIRARD, «Violence and Religion», The Hedgehog Review, primavera, núm. 6, 1, 2004, p. 11.

28. Creo que debemos introducir, siquiera de forma aclarativa, una nota sobre la etimología del "chivo expiatorio». Esta expresión se remonta al caper emisarius de la Vulgata, interpretación libre del griego apopompaios («que aparta los castigos»). En el texto bíblico hebreo significa «destinado a Azazel» (antiguo demonio del que se decía que habitaba en el desierto).

29. E. DuRKheim, Las formas elementales de la vida religiosa, Madrid, 1982, p. 363.

30. R. Girard, $M N M, 1985$, p. 185. 
Según Girard, todos los rasgos atribuidos al siervo lo predisponen para el papel de un verdadero chivo expiatorio humano:

El Señor quiso triturarlo con su sufrimiento y entregar su vida como expiación.

(Is. 53,6)

Jesús de Nazareth es el más grande de los profetas, aquél que representa y trasciende a todos ellos. Con él se produce un desplazamiento, a la vez minúsculo y gigantesco, que aparece como una extensión directa del Antiguo Testamento, pero, asimismo, constituye una formidable ruptura. Acontece por primera vez la eliminación de lo sacrificial, es el final de la violencia divina, es la verdad de todos (no todos menos uno) la que se establece.

Jesús se nos presenta como la víctima inocente de una colectividad en crisis que, al menos temporalmente, se coaliga contra él. Todos los grupos acaban dando su adhesión explícita o implícita a esa muerte: la gente de Jerusalén, las autoridades religiosas judías, las autoridades políticas romanas y hasta sus discípulos, ya que quienes no lo traicionaron o lo negaron activamente huyeron o permanecieron pasivos. Jesús opone al ritualismo fariseo una frase antisacrificial de Oséas:

Misericordia quiero, que no sacrificio.

(Mt. 9,13)

En los Evangelios, la pasión de Cristo se nos presenta ciertamente como un acto que presenta la salvación a la humanidad, pero no como un sacrificio. A juicio de Girard, el texto fundamental ${ }^{31}$ que nos presenta a Dios como ajeno a todo tipo de violencia, deseoso de ver a los hombres renunciar a la venganza, está en el Evangelio de san Mateo:

Habéis oído que se dijo: Amarás al prójimo, y odiarás a tu enemigo. Pues os digo: Amad a vuestros enemigos y rogad por los que os persiguen, para que seáis hijos de vuestro padre celestial, que hace salir su sol sobre buenos y malos, y llover sobre justos e injustos.

(Mt. 5, 43-45)

Jesús, portador de lo divino, en su encarnación humana asume el «desgarro» 32 , la fisura, el «ahí doloroso» (recordemos las palabras de impotencia angustiosa y de abandono definitivo de Jesús en la cruz cuando grita: «Eli, Eli, lama Sabachtani», (Salmo 22)) y violento de la comunidad y propone una remitologización que aparece como realización simbólica en donde el

31. R. Girard, $M N M, 1985$, p. 214.

32. A. Ortiz-Osés, «La Escuela de Eranos», en Letras de Deusto, enero, 1993, p. 13. 
mito del pan y el vino (metáfora) simbolizan una donación de sentido a través del rito de la presencialización de lo sagrado (sacramento) a través de Jesús de Nazareth. Al asumir el Mal de todos, Jesús anuncia una reconciliación sin segundas intenciones y sin intermediarios sacrificiales. La ética del Sermón de la Montaña ${ }^{33}$ de Jesús propone una alianza ${ }^{34}$ —la tercera, puesto que la primera fue con Abraham y la segunda con Moisés- que extirpará la violencia de la comunidad:

Habéis oído que se dijo:

Ojo por ojo y diente por diente.

Pues, yo os digo que no resistáis al mal;

antes bien, al que te abofetee en la mejilla derecha

preséntale también la otra, al que quiera pleitear

contigo para quitarte la túnica, déjale también el manto.

(Mt. 5, 38-40)

El reconocimiento de Juan el Bautista y de Jesús representa el sello de la autenticidad profética y mesiánica, es el hecho simple y milagroso de que no sucumben al vértigo de la violencia. Jesús está siempre dispuesto a asumir todos los riesgos, siempre dispuesto a pagar personalmente para ahorrar a los hombres el destino terrible que les aguarda ${ }^{35}$. «No hay amor más grande que morir por sus amigos» (Jn. 15,13).

La idea de martirio fue introducida por la Biblia y fue firmemente desarrollada en nuestra cultura a través de los Evangelios. Sin las singularísimas promesas del gran escritor desconocido de la época del exilio que redactó la teodicea profética del sufrimiento, de la desgracia, de la pobreza, de la humillación y de la fealdad (Is. 40-55), especialmente la doctrina del Siervo de Yahvé que enseña y que, libre de culpa, sufre y muere voluntariamente como víctima expiatoria, no habría sido concebible el desarrollo de la doctrina cristiana del martirio del salvador divino ${ }^{36}$. Nietzsche ${ }^{37}$ advierte cómo el Siervo de Yahvé en la tradición profética judía es el primer sujeto histórico que rompe las cadenas de una tradición heredada y sitúa la verdad del lado del que sufre. Ésta es la gran transvaloración de los valores inscrita en la profecía ética judía. Serán las religiones postabrahámicas las que desarrollarán una concepción nueva del martirio. La idea de martirio desplaza gradualmente a la mitología del «asesinato original» común en la religión arcaica. Invierte el mensaje contenido en la mitología arcaica interpretando la historia del acto original de

33. M. Weber, From Max Weber, H. Gerth y C. W. Mills (eds.), Nueva York, 1958, p. 11920.

34. R. N. Bellah, Beyond Belief, Nueva York, 1970.

35. R. Girard, $M N M, 1985$, p. 240.

36. Esta idea está muy bien desarrollada por M. Weber en su obra El Judaísmo antiguo, incluida en sus Ensayos sobre sociología de la religión, Madrid, 1987, p. 21 y s.

37. F. Nietzsche, Werke, II, Zur Genealogie der Moral, Karl Schlechta (comp.), Darmstadt, 1955, p. 771-799. 
violencia, no desde el punto de vista de los asesinos, no desde el punto de vista en que una «banda de asesinos irreverentes» informaría de sus acciones inicuas, sino desde el punto de vista de las víctimas ${ }^{38}$. En lugar de justificar y de ennoblecer la violencia cometida contra un enemigo infiel (usualmente un enemigo atravesado por el mal, de cuerpo defectuoso y criatura extranjera) como un sacrificio necesario para salvar a la comunidad de la perdición, tal como ocurría en los mitos arcaicos, las historias del martirio procedentes de la literatura profética judía, preservadas en la tradición postabrahámica, condenan tal sacrificio como un acto de atrocidad abominable. La diferencia no está tanto en el sacrificio en cuanto tal como en el cambio de interpretación según la cual estas historias denuncian y censuran las intenciones malignas y la ceguera de una turbamulta mientras celebran la rectitud y probidad de la víctima de las masas, culpan a las masas por perseguir víctimas inocentes. La verdad del sacrificio que es revelada en la crucifixión, en la kénosis de Cristo, destruye de una vez por todas la razón de ser de todos los sacrificios. Este misterio es la autohumillación de Dios, la kénosis, que desciende de la infinita majestad de la divinidad, no sólo para tomar la forma de un ser humano en cuanto tal, sino la forma de un ser humano rechazado, burlado y, finalmente, asesinado en las más degradantes circunstancias. Aquí radica la locura redentora ${ }^{39}$ de este Dios hombre. El mártir es alguien que actúa contra todo pronóstico, cuyo juego es un «juego profundo» ${ }^{40}$, no en el sentido de que no sea consciente de su muerte inminente, sino en el sentido de que es consciente de que su sacrificio puede que no sea apreciado en sus justos términos y, a pesar de todo, corre el riesgo, un riesgo infinito sin ningún tipo de seguridad, sólo le acompaña la seguridad ontológica de un futuro que está de su parte, frente a toda la comunidad en su contra. En todos los tipos ideales implicados en esta historia, José y sus hermanos, Job, el Siervo de Yahvé, Jesús de Nazareth, la pretensión "no es acabar con el mito en cuanto tal, sino con un mito» ${ }^{41}$, el que da la razón al asesino, para crear un nuevo mito, cuyo protagonista es el inocente. El acto de la interpretación es el acto fundacional de una nueva cosmovisión que desactiva las causas de la violencia. Lo que en este acto de interpretación comparece es el mal, no como accidente ontológico de lo real, sino como sufrimiento injusto inflingido al inocente. Este mal es el tótem de aquéllos que no pueden aceptar que lo real que muestra el cuerpo de Jesús torturado como parte de la ley divina no es la obscenidad de un poder sádico, sino un tipo de obscenidad distinta, la imagen de Dios colérico como animal vulnerable y chivo expiatorio sangriento, el pharmakos desollado y despedazado del Calvario ${ }^{42}$.

38. Z. BAUMAN, Liquid Life, Londres, 2005, p. 40 y s.

39. P. L. Berger dedica unas maravilosas páginas al análisis de esta paradoja en su extraordinario libro Redeeming Laughter, Berlín, 1997, p. 189 y s.

40. Tomo el término de C. Geertz, La interpretación de las culturas, México, 1986.

41. H. BlumenberG, "To Bring to an End, if not Myth, then at Least One Myth", en: Work on Myth, MIT Press, Cambridge, Mass, 1985, p. 3-34 y 627-638.

42. T. Eagleton, Holy Terror, Londres, 2005, p. 29. 
"Haciéndose pecado», en palabras de san Pablo, esta criatura humillada hace frente a la solidaridad sufriente con todas las víctimas mutiladas por - lo que san Juan llama- los poderes de este mundo, poderes cuya muerte anunciada golpea ahora.

Resistiéndose a una cierta lógica de supervivencia naturalista biologicista, los mártires corren con la liebre en lugar de cazar con los sabuesos. Éstos, como sabemos, cazan en grupo; esta circunstancia da a la liebre poca oportunidad, pero no añade sabiduría o virtud al acto asesino de los podencos, porque no hay sabiduría ni virtud en los meros números. Los cargos lanzados contra la víctima no son más verdaderos por ser gritados en coro. La verdad estaba y sigue estando del lado de la víctima. Sabiendo que «la muchedumbre armada con espadas y porras» escalará rápidamente el Monte de Los Olivos para acabar con él, mientras sus discípulos "perderán la fe», abandonándole y escapándose, Jesús decide proclamar a los pies de la turbamulta: «dejad que se cumplan las escrituras» (Mar, 14). Los mártires son víctimas que saben que van a morir y eligen hacerlo dando a su muerte la significación del testimonio de que hay verdades que no pueden ser borradas ni olvidadas por el hecho de tener en contra a muchas gargantas gritando contra ellas. El martirio significa solidaridad con un grupo más pequeño y más débil, un grupo discriminado, humillado, ridiculizado, odiado y perseguido por la mayoría. El mártir no gana nada desde un punto de vista de la acción racional que repara en el uso de unos medios para obtener unos fines, pero «gana» el futuro, puesto que segrega la semilla simbólica de un dispositivo social antisacrificial.

\section{La segunda metamorfosis: el «mártir» que se convierte en «héroe nacional»}

El maestro dice que morir por $\mathrm{la} \mathrm{Fe}$ es una cosa gloriosa, y papá dice que morir por Irlanda es una cosa gloriosa, y yo me pregunto si hay en el mundo alguien que quiere que vivamos.

(Frank McCourt)

Esto es lo que caracteriza al mártir, a diferencia de la mitología del "héroe nacional», que lucha por una trascendencia intermedia llamada «nación» frente a la trascendencia absoluta de Dios. Entre los fines de aquél están la probidad moral, el arrepentimiento de sus pecados, la redención del alma, en última instancia, mientras que éste último es moderno, calcula las ganancias y las pérdidas, desea que su sacrificio sea pagado de alguna manera. No existe y no puede haber algo así como un "martirio gratuito». No hablamos de pago o de beneficio en sentido monetario, ellos no pueden ser acusados de avaricia, sino de los efectos reales de ese acto social total que supone autosacrificarse por un ideal, por muy político que sea. Haciendo tal propósito más cercano, dan un sentido a su muerte. La trascendencia del valor de ese ideal es el "precio" de la muerte del «héroe nacional». Mientras que el sentido del martirio no depen- 
de de lo que ocurre en el mundo después, el sentido del heroísmo, sí. Digamos que el «mártir» no está preocupado por las consecuencias imprevistas de su determinación, mientras que el "héroe» da una gran importancia a la correcta interpretación de su acto. En su reencarnación moderna, el «héroe» es un renacido $^{43}$ en el umbral de una nueva época de nation building and citizenship. No debemos olvidar la invocación y resurrección en la República francesa de la fórmula romana antigua de pro patria, que después de siglos recuerda a la noción cristiana de «mártir» aplicada a los cruzados y a otros combatientes de la «guerra santa». El siglo XIX ve cómo, uno tras otro, los grandes imperios políglotas construidos a lo largo de cientos de años han ido desintegrándose - esos vastos ámbitos una vez dominados desde Londres, Estambul, Moscú, Madrid, Lisboa, La Haya, Viena, París, incluso Adis Abeba. En el umbral de la era moderna, Europa estaba dividida en dominios dinásticos y en un gran mosaico de grupos étnicos y lenguajes, cada uno de los cuales estaba dispuesto a asumir el estatus de un estado nación (en donde el estado apunta a defender la unidad de los intereses nacionales mientras que la nación ejerce la soberanía estatal sobre el territorio que pretende), pero pocos de estos grupos alcanzan la realidad estatonacional, se da algo así como, utilizando terminología darwiniana, una lucha por la adaptación a un entorno sociohistórico nuevo en donde concurren muchas «minorías» reacias a abandonar sus propios modos de vida disolviéndose en medio de la cultura triunfante. La construcción y el fortalecimiento del Estado nación produce una lucha por la supervivencia de los más aptos, de los más fuertes, a través del uso del poder militar —el Estado nación sin ejército sería como un eunuco en un harén-, creando y manteniendo las fronteras externas frente a los vecinos, así como silenciando, aislando e incapacitando al infiel, a los no leales, o a los sospechosos de no estar plenamente convencidos del poder del nuevo Estado nación. En este caldo de cultivo es donde renace el «héroe». Las emergentes naciones precisan del poder estatal para sentirse seguras y el estado precisa del patriotismo nacional para sentirse poderoso, tanto hacia el interior como hacia el exterior ${ }^{44}$. Cada uno necesita al otro y ambos precisan de sujetos miembros dispuestos a sacrificar sus vidas por tal ideal. El tiempo del Estado nación es un tiempo de heroísmo, de patriotismo heroico.

$\mathrm{Al}$ cambiar el contexto social, cambian sus principales protagonistas. El sociólogo Emile Durkheim, en su estudio Las formas elementales de la vida religiosa, de 1912, proponía una interesante interpretación del totemismo. «El tótem [decía] es ante todo un simbolo, una expresión material de alguna otra cosa, ¿pero de qué? Del análisis al que hemos dedicado atención se desprende que tal símbolo expresa y simboliza dos tipos de cosas diferentes: por un lado, constituye la forma exterior y sensible de lo que hemos llamado el principio o Dios totémico, Pero, por otro lado, constituye el símbolo de esa sociedad 
determinada llamada clan. Es su bandera, es el signo por medio del cual cada clan se distingue de los otros, la marca visible de su personalidad, marca que llevan sobre sí todos aquéllos que forman parte del clan en base a cualquier título, hombre animal y cosas. Así pues, si es a la vez el símbolo de Dios y de la sociedad, ¿no será porque el Dios y la sociedad no son más que uno? [...] El Dios del clan no puede ser más que el clan mismo, pero hipostasiado y concebido por la imaginación en la forma de las especies sensibles del animal o vegetal utilizados como tótem ${ }^{45}$. Eso que Durkheim observa en el simbolismo de las primeras sociedades humanas lo podemos trasladar al nacimiento de la realidad nacional, al calor de la Revolución Francesa, por ejemplo, a la definición de la nación como forma de identidad colectiva moderna que realiza el abate Sieyès en su celebrado Qu'est-ce que le Tiers État? de 1789, y nos daremos cuenta que se ha producido una transferencia de numinosidad de «lo absolutamente otro" (Dios) al "otro generalizado» (el pueblo de una nación, al clan, en los términos de Durkheim), se ha substituido la presencia de seres sobrenaturales por una sacralización del constructo social del «pueblo de una nación", éste comparece como el nuevo dios secularizado de nuestro tiempo, como nuevo objeto de culto, que generará sus propios altares sacrificiales, como muy bien han apuntado R. N. Bellah ${ }^{46}$, E. Gellner ${ }^{47}$ y J. R. Llobera ${ }^{48}$. El leitmotiv del abate Sieyès era situar a la nación como entidad moral preexistente a todo fenómeno social y a toda institución social. "La nación es antes que todo. Es el origen de todo. Y siempre será legal, es la ley misma [...] La imagen de la Patrie es la única a la que es permisible tributarle culto» ${ }^{49}$. Según Durkheim, lo que adora la sociedad en el culto religioso es su propia imagen hipostasiada. Lo que define al fenómeno religioso no es el contenido, sino la forma, por tanto, lo que es relevante no es tanto la presencia o ausencia de seres sobrenaturales, sino el potencial religador de determinados símbolos para todos los miembros del grupo. Del imaginario social de la revolución francesa emerge una nueva fe cuyo objeto de culto es la nación. Ésta comparece como «nuevo dios» secularizado al que reverencia el "héroe nacional». Benedict Anderson, en Imagined Comunities, apunta que la gente está dispuesta a morir por su nación. El nacionalismo es un trazo prolongado de trascendencia dentro del mundo secularizado. Como Dios, la nación es inmortal, indivisible, englobante de forma invisible, sin origen ni fin, merecedora de nuestro mayor amor y entrega. "Rellenar el lugar del Bien Supremo es lo que define la noción moderna de nación» ${ }^{50}$. «Lo sagrado», por tanto, no es rechazado, sino más bien resituado como el objetivo de un «relevo poco amistoso», desplazado bajo diferente administración y puesto al servicio del emergente Estado nación. Lo

45. E. DurKheim, Las formas elementales de la vida religiosa, Madrid, 1982, p. 194.

46. R. N. Bellah, "Civil Religion in America», en: Beyond Belief, Nueva York, 1970, p. 175 y s.

47. E. GELLNER, Naciones y nacionalismo, Madrid, 1988, p. 20.

48. J. R. Llobera, The God of Modernity, Londres, 1995, p. 187, 206 y 221.

49. E. SIEYĖS, Qu'est-ce que le Tiers État, Ginebra, 1970.

50. S. ZizEK, Tarrying with the Negative, Londres, 2003, p. 222. 
mismo le ocurre al «mártir», que es incluido dentro de las listas del nuevo Estado nación bajo el nombre de «héroe».

Volvemos retrospectivamente a la cultura abrahámica, en donde encontramos el ejemplo más impresionante de nuestra propia tradición cultural tal como nos lo narra el Génesis: "Y Dios puso a prueba a Abraham y le dijo, coge a Isaac, tu único hijo, a quien más amas, llévalo al país de Moriah, y ofréceme ahí, en la montaña, su sacrificio» (Génesis, 22, 1-2). Abraham no llega a consumar el mandato divino porque el mismo Yahvé detiene su mano asesina justo cuando iba a asestar la puñalada mortal a su hijo («sangre de su sangre»). J. Zulaika y W. Douglass ${ }^{51}$, apoyándose en la exégesis veterotestamentaria de Kierkegaard, apuntan que Abraham no se rigió por el baremo crítico de la razón, sino que no sintió la necesidad de ir más allá de la fe, algo que para nosotros nunca puede ser éticamente aceptable. Abraham no es un héroe trágico, sino algo bastante diferente: "o bien un asesino $o$ un creyente" ${ }^{52}$. Y en medio de esta paradoja es donde se sitúa la ortopraxis del «héroe nacional». Aunque el moderno patriotismo heroico haya substituido el «reino de Dios» por el "pueblo de la nación» y le haya transferido a éste una buena parte de la numinosidad de aquél, su modelo de acción social sigue siendo un «juego profundo ${ }^{53}$, un juego sagrado en el que se dramatiza ritualmente ${ }^{54}$ el sentido de la vida y de la muerte propia y de los demás. En este juego se juega con la "experiencia límite», con la muerte, con la posibilidad de la absoluta imposibilidad. Su acción se sitúa en lo que Michael Walzer ${ }^{55}$ llama «compromiso cultural profundo" (matarás en el nombre de...) frente al más "débil procedimiento ético» (no matarás en nombre de nada ni de nadie). Ahí radica su grandeza, en los términos de la mitología arcaica, y al mismo tiempo su tragedia, según la nueva interpretación inaugurada por el «último mártir», Jesús de Nazareth. Al interpretar un episodio como el sacrificio de Isaac, en tanto que prefiguración del sacrificio de Cristo, de forma que en el primero está anunciado y prometido el segundo, se establece una conexión entre dos acontecimientos que ni temporal ni causalmente se hallan entrelazados. Esa misma

51. Véase, sobre esta interpretación del sacrificio de Isaac, el excelente texto de J. ZULAIKA y W. Douglass, Terror and Tabu. The Folies, Fables and Faces of Terrorism, Londres, 1996, cap. 5 , p. 123 y s.

52. S. KierKegaARD, Temor y temblor. Diario de un seductor. Madrid, 1975, p. 95 y s.

53. Zulaika y Douglass adoptan este concepto de C. Geertz para ejemplificar el tipo de acción social del agente vengador.

54. Randall Collins ha analizado recientemente los rituales de interacción que conforman los sentimientos colectivos en varios asentamientos. Ver su trabajo: Interaction Ritual Chains, Princeton, 2004, cap. 1, 2 y 3. Para observar los análisis de los rituales que subyacen a la formación de la identidad colectiva, ver los trabajos de Jesús CASQUETE, «The Powers of Identity», Social Movements Studies, 2006, en prensa, y El poder de la calle. Ensayos sobre movimientos sociales y acción colectiva, Centro de Estudios Políticos y Constitucionales, Madrid, 2006.

55. M. Walzer adopta otro concepto de C. Geertz, el de "descripción densa», que le sirve para determinar las concepciones «fuerte» y «débil» de la moralidad. Véase M. WALZER, Thin and Thick, 1994. 
conexión es la que establecemos entre ambos aconteceres y éste otro más reciente representado por la nueva mitología del «héroe nacional». Es un ricorso mitológico, una actualización de una potencialidad imaginaria a través de la fuerza de la acción humana.

Este núcleo no racional de la nación ha sido alcanzado y desencadenado a través de símbolos nacionales, de la poesía nacional, de la música y también del uso de metáforas familiares donde aparece la «llamada» de los "fantasmas», de los «ídolos de la tribu», cuyas voces, representando a seres míticos de la propia memoria colectiva, pretenden evitar la amnesia de la propia historia. Así sucede con Cathleen ni Houlihan, el trabajo más nacionalista y más propagandista escrito por William Butler Yeats en 1902. A juicio de Conor Cruise $\mathrm{O}^{\prime} B_{r i e n}{ }^{56}$, ésta es la poesía más impresionante de propaganda nacionalista que jamás se haya escrito. Cathleen ni Houlihan es un ser mítico, el más conocido de un elenco de nombres femeninos usados para personificar en la poesía gaélica a Irlanda. Cathleen adopta la forma de "Una Pobre Vieja», que visita el hogar de una próspera familia de granjeros católicos, los Gillane, que se preparan para el matrimonio de su joven hijo Michael. La Vieja está ahí para cancelar el matrimonio y reemplazarlo con un sacrifico sangriento dentro de una revolución nacionalista. Así se expresa la Vieja: "Algunas veces mis pies están cansados y mis manos quietas, pero no hay tranquilidad en mi corazón. Cuando la gente me ve tranquila, piensa que he envejecido y que toda emoción se ha evaporado de mi [una referencia a la desaparición aparente del nacionalismo revolucionario en Irlanda a comienzos del siglo XX]. Pero si el problema radica en $\mathrm{mi}$, debo hablar a mis amigos [a los nacionalistas revolucionarios, a los "héroes nacionales»] [...] Si alguien quisiera ayudarme, debiera ayudarme a mi [a Irlanda], debiera dármelo todo [incluida la propia vida]». En la obra, las conclusiones finales de Cathleen exponen las condiciones de su servicio y cómo el servicio puede ser recompensado. Esto se pone de manifiesto cuando ella abandona la casa de los Gillane entonando la siguiente canción:

Ellos serán recordados siempre.

Ellos vivirán siempre.

Ellos hablarán siempre.

La gente los oirá siempre ${ }^{57}$.

La Pobre Vieja, Cathleen ni Houlihan, no sólo expresa, a través de una metáfora, a la nación irlandesa herida, sino que además aparece como sacramento, como la llamada al ritual, al sacrificio que suture la herida en el nombre de la patria. Yeats, por supuesto, no inventa Cathleen ni Houlihan, ella ha estado ahí, siglos y siglos, en poemas e historias. Yeats la trae a la vida —a un tipo de muerte en vida — a través de su escenificación teatral. El espí-

56. Las referencias a Cathleen ni Houlihan de W. B. Yeats las tomo de C. Cruise O'BrIEN, Ancestral Voices. Religion and Nationalism in Ireland, Dublin, 1994, p. 61 y s.

57. C. C. O’Brien, op. cit., 66 y s. 
ritu de Cathleen ni Houlihan reaparecerá unos años después en los escritos y sobre todo en la praxis política de una de las personalidades más carismáticas y extraordinarias del siglo XX, el alma del levantamiento irlandés de 1916, Patrick Pearse ${ }^{58}$. Según él, el pueblo, que será señor en Irlanda cuando ésta sea libre, englobará a aquéllos que hayan obedecido las voces convocantes de ciertos fantasmas privilegiados: los fantasmas de los muertos que nos han legado una confianza, una fe, a los vivos..., fantasmas de la nación. Pearse reinterpreta el sacrificio de Cristo dentro de un contexto nacional. El sacrificio redimirá a la nación como Cristo redimió al mundo. Pero, para esta nueva misión sacrificial será preciso disponer de un mesías colectivo, que no puede ser sino el pueblo. Dentro de este destino fatídico elegido, no viene mal recordar que la muerte adquiere sentido en y por la vida, situando al ciudadano pacífico frente al beligerante "héroe nacional», como con gran elocuencia lo pone de manifiesto el premio Pulitzer de literatura Frank McCourt, refiriéndose al caso irlandés:

El maestro dice que morir por $\mathrm{la} \mathrm{Fe}$ es una cosa gloriosa,

y papá dice que morir por Irlanda es una cosa gloriosa,

y yo me pregunto si hay en el mundo alguien que quiere que vivamos ${ }^{59}$.

La moderna reencarnación del «héroe» —alguien que muere para asegurar la supervivencia de la nación- representa un efecto colateral de lo que George L. Mosse ha llamado la «nacionalización de la muerte» ${ }^{60}$, donde se mezclan dos principios: el de pertenencia a un grupo social y el de la defensa violenta de tal grupo. "La muerte en la guerra de un hermano, del marido o de un amigo» ha sido vista - justo como ocurría con la muerte de un mártir en el pasado - como un sacrificio; pero, «ahora, al menos en público, la ganancia parece valer más que la pérdida personal». La muerte del héroe es trascendida tal como fue trascendida la muerte del mártir, esta vez no por la salvación del alma inmortal del muerto, sino por la inmortalidad material de la nación $^{61}$. La modernidad no está exenta del culto (nacional) a los muertos, a los caídos por la causa de la nación, los Gefällendenkmaler o Heldenhaine, los jardins funébres, los Parchi della Rimembranza, todos estos monumentos a los

58. Sobre el nacionalismo místico de Patrick Pearse, ver, asimismo, C. C. O’BrIEN, op. cit., 96 ys.

59. F. McCourT, Las cenizas de Ángela, Madrid, 1997, p. 120.

60. G. L. Mosse, Fallen Soldiers, Oxford, 1990, p. 34 y s., ver, del mismo autor: The Nationalization of the Masses, Nueva York, 1975, donde Mosse analiza el proceso de «hacerse alemán». Eugen Weber ha estudiado el mismo proceso de "hacer a los campesinos ciudadanos franceses» en Peasants into Frenchmen, Stanford, 1976. Linda Colley ha estudiado el caso inglés de forjamiento de la nación en Brittons, Londres, 1992. José Álvarez Junco ha estudiado el caso español en Mater Dolorosa, Madrid, 2001.

61. Z. BAUMAN, Liquid Life, op. cit., 44.

62. Ver la importante compilación de R. Koselleck: Der Politische Totenkult, Munich, 1994, también la contribución de H. LÜBBE, Im zug der Zeit, Heidelberg, 1992, p. 37-55. 
héroes caídos ${ }^{62}$ ponen de manifiesto que la autoimagen colectiva de la nación se articula sobre una comunidad mnemónica en donde la conformación del pasado tiene una gran importancia en la experiencia del presente. Como afirmaba Marx: "La tradición de todas las generaciones muertas oprime como una pesadilla el cerebro de los vivos» ${ }^{63}$. El objetivo es dejar que los vivos sepan que sólo el momento de la muerte en el campo de batalla cuenta y retrospectivamente define el significado de la vida.

Ahora bien, el supremo acto de fe de Abraham (o de los autoproclamados mesías individuales posteriores, es decir, los «héroes nacionales») tiene su contraparte en la pérdida de fe de Isaac. La idolatría del padre abre los ojos del hijo, la paradoja abre el discurso de la moralidad del asesinato, aprendemos que la rendición a los valores sólidos incuestionables, bien sea en clave religiosa o en clave profana, conduce a la barbarie última de repudiar a la humanidad. Es enormemente arriesgado mantener o escudarse en la premisa de que «Dios o el pueblo están de nuestro lado». Isaac se libera de la teleología e imaginería de su padre y el nacimiento de una nueva cultura es posible. En su impresionante novela, Sacrifice of Isaac, Neil Gordon ha aplicado la parábola de Isaac al ejército israelí. Un hijo reflexiona sobre su padre, Yossef Benami, un profesor y general que es un héroe nacional israelí, y cuyo otro hijo, Danni, ha desertado del ejército durante la invasión del Líbano en 1982. En medio de una discusión familiar, la esposa de Benami le replica: «Yossi, ach, ¿cómo puedes ser tan imbécil? [...] Tu propio hijo te ha dejado, y tu piensas que se trata de una historia sobre los judíos. Tu hijo se ha ido. Tu hijo se ha ido. ¿Dónde está el jodido simbolismo?» ${ }^{64}$. Más tarde, en la novela, el «tu hijo se ha ido" se convierte en "tu has matado a tu hijo». Al final Benami, para quien "no esperar morir por otra cosa que no sea Israel es impensable», ha sacrificado a su padre, a su mujer y a sus hijos, no a los ángeles enviados por Dios, como aparece en el Isaac de Caravaggio, «sino mucho peor: a una idea, a un país, a un país de soldados». Como en el Isaac de Kierkegaard, el Danni de Gordon se da cuenta que su padre se ha convertido en un verdugo, y los árabes no se sienten como el enemigo, ellos se sienten como él mismo. Quizás está pensando en lo mismo Amos Oz cuando afirma: «dentro de la sociedad israelí, los territorios (ocupados) sólo son el lado oscuro de nosotros mismos (es decir, de la sociedad israelí) ${ }^{65}$. No es Dios el que pone a prueba a Abraham, sino éste el que pone a prueba a Dios. Sólo una democracia deliberativa basada en ciudadanos libres permite atenuar las consecuencias perversas de las ambivalentes derivas de las culturas del heroísmo, incluido el heroísmo patriótico.

63. K. MARX, «El Dieciocho Brumario de Luis Bonaparte», en Obras Escogidas, vol. 1, Madrid, 1975 , p. 233.

64. N. GoRdON, Sacrifice of Isaac, Nueva York, 1997, p. 60.

65. A. Oz, La tercera condición, Barcelona, 1994, p. 44. 


\section{La tercera metamorfosis: entre la cultura de la celebridad y el suicida bomba}

No debes pensar que esos que fueron abatidos

por la causa de Alá están muertos.

Ellos viven, y bien asistidos por su Señor.

(Corán, sura 3, verso 169)

En cuestión de coraje (una virtud moralmente neutral), sea lo que fuere lo que digamos de los perpetradores de la matanza del martes, ellos no eran cobardes.

(Susan Sontag)

En las sociedades que han prohijado estas metamorfosis o máscaras de la violencia, hoy pobladas de satisfechos consumidores, ocupados con sus propios asuntos, que a fin de año se encargan de celebrar sus éxitos en la bolsa, en el amor, en el deporte o en el ejercicio de su profesión, pareciera que hemos extirpado al monstruo de la violencia de la facies de la sociedad, no dejando lugar al mártir o al héroe, en un contexto de modernidad líquida ${ }^{66}$ caracterizada por la gratificación instantánea y por el hedonismo rampante, es decir, por aquel tipo social que Weber, con tanto acierto, dibujó al final de la Etica protestante, «hedonista sin espíritu, gozador sin corazón». Pero una mirada más atenta a las profundidades de lo social nos da cuenta de un cierto retorno de la violencia con una nueva máscara, es decir, al lado de la veneración de la cultura de la celebridad, la violencia reaparece bajo la máscara del terrorista nihilista que analizaremos a continuación. Si el «héroe nacional» surgió al calor del ciudadano soldado ${ }^{67}$, como su lado sombrío, después de la revolución francesa, el nuevo agente provocador tardomoderno surgirá como el contramodelo incapaz de ser domado por la notoriedad que emana de la cultura de la celebridad moderna.

El suicida bomba ${ }^{68}$ no es algo cuyo monopolio sea atribuible exclusivamente al islam, forma parte de las tres grandes tradiciones monoteístas, pero es en aquél donde ha alcanzado sus perfiles más característicos y aterradores. Su praxis nos afecta profunda y poderosamente. Nos recuerda que hay personas que consideran que su lucha — sea cual sea su causa- es más importante que sus propias vidas. Agitan el miedo dentro de nosotros, tiran de la alfombra bajo nuestros pies. No hay forma de desquitarse contra atacantes que luchan, no

66. Ver, al respecto, el trabajo de Z. BAUMAN, Liquid Life, Londres, 2005, p. 80-116.

67. M. JANOWITZ, «Militärische Institutionen und Staatsburgerschaft», en: Knöbl y Schmid (eds.), Die Gegenwart des Krieges, Frankfurt, 2000, p. 131.

68. Un excelente perfil psicológico del hombre bomba lo encontramos en la obra de D. Grossman: La muerte como forma de vida, Barcelona, 2000. También en la obra de C. ReUTER, Mein Leben is eine Waffe, Munich, 2000. 
orientados exclusivamente a matar gente, sino que se autosacrifican en tales acciones. Aniquilan toda la lógica del poder desde el momento en que no es posible situar ninguna amenaza contra alguien que no desea sobrevivir. La presunción de un autointerés racional individual y un miedo a la muerte caracterizan respectivamente al funcionamiento del mercado y al poder del Estado, pero, en el caso del suicida bomba, este supuesto queda brutalmente cancelado. El miedo a la muerte ha sido un importante instrumento de poder desplegado tanto por el Estado como por las castas sacerdotales en el cristianismo y en el islam. El tabú contra el suicidio ha reforzado el poder de la religión, debido a la creencia monoteísta convencional de que sólo Dios puede decidir quien vive y quien muere. Pero, en el caso que nos ocupa, hacemos frente a gente que se rebela no sólo contra el Estado, sino también contra otros candidatos de autoridad suprema, religiosa o secular. Los suicidas bomba desafían simultáneamente a la última sanción, convirtiendo al más alto poder en impotente. Lo que experimentamos a partir del 11 de septiembre de 2001 es una reinvención del arquetipo histórico que muchos historiadores políticos pensaron había desaparecido, el "mártir». Éste dice a su propia gente: «sigue mi ejemplo, la causa — sea cual fuere— es más grande que nuestras propias vidas» ${ }^{69}$. Enésima y fatídica repetición histórica de una absolutizada ética de la convicción a costa de la ética de la responsabilidad. Proclaman al mundo exterior: nos produce más miedo la humillación que la muerte y, por tanto, no tenemos miedo de vuestros ejércitos bien entrenados y equipados, de vuestro arsenal de alta tecnología. En el potencial reclutamiento del suicida bomba, cuanto más privado de poder se sienta el activista, más dramáticamente le exaltará su propia muerte. Esto representa lo que podíamos llamar el «poder de los sin poder" (the power of the powerless) y coextensivamente, mirado desde nuestro punto de vista, el «sin poder de los poderosos» (the powerlessness of the power$f u l)^{70}$. En su propia persona, él se ha percatado de aquel dictum de Andy Warhol según el cual todo el mundo alcanza «sus quince minutos de fama». El islam y el cristianismo están repletos de casos relacionados con el martirio, incluso hoy mismo, las plazas centrales en el corazón de Beirut y Damasco, ambas se llaman "plaza de los Mártires». Los viejos ideales martiriológicos ganan adeptos en distintos lugares hoy día.

Pero, ¿qué les lleva actuar de esta manera a estos activistas?, ¿qué les lleva a inmolarse juntos, como ocurrió el 11 de septiembre de 2001 en Nueva York y en sus sucesivas acciones de Bali, Madrid, Londres...? Se ha difundido la idea de que estos activistas habrían sido objeto de un lavado de cerebro, de un entrenamiento mental que utilizaba la privación del sueño, el suministro estratégico de comida y drogas, la hipnosis, sobreestimulando al activista y manipulando sus sentimientos de culpa y de miedo con la pretensión de alterar su autoestima. Se le da un nuevo nombre, nueva ropa y se le conmina a seguir

69. F. JosRojaVAR, Los nuevos mártires de Alá: La realidad que esconden los atentados suicidas, Barcelona, 2003, p. 9-28.

70. C. Reuter, Mein Leben is eine Waffe, Munich, 2002, p. 9-32. 
rituales que refuerzan su nueva identidad. El alma del atacante es vista como el disco duro de un ordenador que puede ser reprogramado: "Aquí tienes a un adolescente de los arrabales. Primero, se le pone en una escuela coránica, después pasa varios meses en un campo de entrenamiento. Se le socializa en la disciplina militar, en ejercicios ascéticos y en la meditación. Su cerebro es lavado y vaciado y después rellenado con los nuevos contenidos del orden secreto [...] Todo su rostro expresa una sonrisa de eterna bienaventuranza» ${ }^{71}$. Este escenario podría funcionar bien en los filmes de Hollywood, pero el mundo real sigue otras pautas. Tampoco resultan convincentes las explicaciones que proceden a situar las causas de este activismo suicida en la miseria permanente de grandes masas de población dentro de la amplia geografía del islam, ya que, si esto fuera así, la mitad de la población somalí ya se hubiese autoinmolado. Los ataques suicidas son un fenómeno altamente complejo. ¿Por qué grupos como Hamás, Hezbollah, la OLP y otras organizaciones guerrilleras palestinas, así como los mujahidines en Bosnia y Kosovo, usan estos procedimientos, mientras, por ejemplo, el IRA en Irlanda del Norte, las Brigadas Rojas en Italia, ETA en España, Sendero Luminoso en Perú, Aum Shinrikyo en Japón no lo hacen? ¿Por qué comienza este fenómeno en el mundo islámico y por qué se ha movido más allá de él, en algunos casos? ¿Por qué grupos sin vínculos con el islam, como el grupo secularizado PKK en Turquía o los separatistas Tigres Tamiles (la mayoría de ellos hindús) adoptan el asesinato a través del suicida bomba como arma? Esta variedad de asesinato inicia su renacimiento moderno a comienzos de la década de 1980, en los campos de batalla de la guerra irano-iraquí, donde miles de jóvenes iraníes, cada uno de ellos con una pequeña llave del Paraíso en su cuello, cargaron hacia las posiciones de las ametralladoras iraquíes en el nombre de Dios y del ayatollah Jomeini. Es como si el viejo líder carismático hubiese cogido un antiguo instrumento musical silenciado y lo hubiese comenzado a tocar. Movilizando los antiguos mitos sacrificiales del islam chiíta, una secta rebelde nacida hace 1.300 años en una revuelta contra los califas gobernantes, Jomeini «despierta» la noción de autosacrificio como un arma de gue$\mathrm{rra}^{72}$. Mientras, retrospectivamente, este modo de proceder que cuesta miles de vidas inocentes sin conducir a ninguna victoria militar apreciable, pudiera parecer absurdo, sin embargo, se convierte en una valiosa «arma exportable». Los Guardias de la Revolución iraníes la llevan al Líbano para ayudar a sus hermanos religiosos, los chiítas libaneses, y construyen Hezbollah, el «Partido de Dios». Lo que aquellos inventaron, éstos lo desarrollan a la perfección. Los chiítas de Hezbollah fueron los primeros en crear la «marca» del suicida bomba atacante como una "operación de martirio» y la correspondiente mitología moderna de los autoelegidos para el martirio.

Los suicidas no son misiles con dos piernas, máquinas asesinas que vienen de no se sabe dónde cargados con la ira de Dios o con las órdenes asesinas de 
un líder de culto que los ha programado. Ellos son gente, individuos con familias y enraizados dentro de una sociedad. Sólo lograremos entenderlos si comprendemos el entorno espiritual e intelectual del mundo en el que viven, las ideologías que los forjan y los mitos con los que crecen, incluso cuando éstos son tan devastadoramente paranoicos como la existencia de una conspiración judeo-occidental global contra el islam, una teoría que Osama bin Laden continúa promulgando con el objetivo de atraer y explotar millones de adhesiones dentro del mundo islámico. En la medida en que uno no puede entender la Unión Soviética a partir de los textos de Marx o el nazismo a partir de los textos de Gobineau o Nietzsche, es absurdo, igualmente, intentar comprender a Bin Laden a partir de los textos del Corán. En efecto, el Corán endorsa la guerra santa, Marx llama a la dictadura del proletariado y Nietzsche apela a la bestia rubia. ¿Y qué? Los regímenes de terror precisan de textos tradicionales por razones ideológicas, ellos usan y abusan de tales textos como ideologías. Nuestro terror global contemporáneo utiliza la religión como un arma ideológica, como un puro medio para sus fines profanos. La ideología es simple mascarada. Los nuevos terroristas precisan inventar una grand narrative, necesitan reinventar la tradición y, de hecho, es lo que hace Bin Laden en sus vídeos televisados, durante los que comienza una historia de frustración musulmana que se retrotrae a los cruzados que ocuparon Jerusalén, continuando con la reconquista de España (al-Andalus) y arribando a la reocupación judía, más reciente, de Jerusalén. No son guerras de religión las que están en liza, sino guerras muy profanas ${ }^{73}$, con fines muy profanos, aunque sus medios de movilización de masas sean religiosos. Entre las causas del martirio ofensivo ${ }^{74}$, sin duda alguna está la humillación, la autoimagen según la cual Occidente proclama: «echad a la basura el Corán y comprad videoclips de Madonna» ${ }^{75}$. Estos jóvenes están atrapados. El fundamentalismo apocalíptico —en los medios - y nihilista - en los fines - no es un simple retorno a un modo premoderno de relación con la religión, es la respuesta temerosa a la modernidad, percibida más como amenaza que como oportunidad ${ }^{76}$. El medio arma del que se sirven es la religión, o esa amalgama religiosa que sirve como instrumento de protesta en un

73. S. BenhabiB, «Unholy Wars», Constellations, 9, 1, 2002, p. 34-46. Ver también el trabajo de J. L. Esposito: Unholy War. Terror in the Name of Islam, Nueva York, 2002.

74. F. Josrojavar distingue este martirio, que implica al suicida y a los inocentes sacrificados, frente al martirio clásico, que implicaba únicamente al mártir. Ver su obra citada, p. 14 y s.

75. Quizás la expresión más radical y extrema de esta bipolaridad cultural es la que establece Benjamin Barber en Jihad versus Mcworld, en donde «la Jihad pretende una política identitaria sangrienta, mientras que el Mcworld pretende una economía pacífica de la política» (Jihad versus Mcworld, Nueva York, 2001, p. 8). El propio occidente es corresponsable de esa imagen según la cual los americanos serían los nuevos romanos modernos, que ofrecen, por una parte, un militarismo que lo impregna todo y, por otra, una industria del ocio a base de juegos sangrientos, guerra y circo como dispositivos de amansamiento de masas. Ver esta idea en P. SLOTERDIJK, Normas para el parque humano, Madrid, 2000 , p. 32.

76. J. HABERMAS, «Terrorism and the Legacy of Enlightment», en: J. HabERMAS y J. DerRIDA, Philosophy in a Time of Terror, Chicago, 2003, p. 18. 
mundo postideológico de activismo religioso ${ }^{77}$. Los fracasos del Estado, a menudo económicos, políticos y culturales, son experimentados con frecuencia de forma personal como humillación y como alienación, como una pérdida de la identidad. La respuesta en forma de guerra "cósmica» ${ }^{78}$ es una característica realmente consistente de todos estos casos. El suicida bomba se ve a sí mismo como un soldado en lo que él imagina como una batalla sagrada. Es una guerra "cósmica» en el sentido de que es más larga que la propia vida. Evoca grandes batallas del pasado y están relacionadas con conflictos metafísicos entre el bien y el mal. A menudo, los activistas emplean imágenes de la guerra sagrada que se encuentran en todas las tradiciones religiosas - como las batallas descritas en el Antiguo Testamento, las cruzadas cristianas, las batallas épicas del hinduismo y del budismo y la idea islámica de la jihad. Lo que hace particularmente salvaje a la violencia religiosa es que sus perpetradores han situado tales imágenes religiosas de lucha divina — guerra cósmica- al servicio de batallas políticas intramundanas.

Lo que hace efectiva a la acción violenta es su anclaje dentro de una red de mitos medievales reinventados y dentro de la cultura popular de veneración del héroe. La voluntad de imitar al otro en la muerte es un rasgo constante entre los jóvenes, para obtener una identidad colectiva, desmarcándose de los demás y constituir una nueva jerarquía de los corazones antes de remitirse a una jerarquía social. «El principio de imitación remite a una sociedad culturalmente unificada y homogénea, en donde las jerarquías tradicionales a base de identidades diferenciadas y bien definidas son cuestionadas. Estamos ante una sociedad en dolorosa gestación, donde la nueva relación social se expresa por la capacidad de imitación de los jóvenes en el martirio, es decir, allí precisamente donde se constituye el nuevo "individuo en la muerte" ${ }^{79}$. Nunca mejor dicho, «la muerte como forma de vida». Ellos pretenden ser recordados póstumamente como héroes, es decir, se fijan más en un fin intramundano que en la recompensa en el otro mundo rodeados de vírgenes. En adición a esta emulación táctica, los atentados se han convertido en un arma de psicología de masas. Se produce lo que podíamos llamar el «efecto Werther» ${ }^{80}$, en el que el suicida se convierte en un ídolo para aquéllos que pretenden emularlo, «infectando» a sociedades enteras. Cuanto más moderna, democrática y diferenciada es una sociedad, más efectivo es el ataque del terror moderno y posmoderno, puesto que éste actúa como un «hecho social total» inmune a la diferenciación que se proyecta generando la máxima resonancia a través de los

77. Ver al respecto el trabajo de B. LEWIS, The Crisis of Islam. Holy War and Unholy Terror, Nueva York, 2003, y también el de B. LinCOLN, Holy Terror. Thinking About Religión After september 11, Chicago, 2003.

78. Ver esta noción en M. JUERGENSMEYER, Terrorismo religioso, Madrid, 2001, p. 169-191, y también del mismo autor en "¿Is Religión the Problem?», The Hedgehog Review, primavera, vol. 6, 1, 2004, p. 28-29.

79. F. JosrohaVAr, op. cit., p. 161-162.

80. No olvidemos que en la novela de Goethe, Los sufrimientos del joven Werter, el protagonista se suicida. 
medios de comunicación simbólica generalizada, ya que no debemos olvidar que las guerras posmodernas se ganan y se pierden por la televisión ${ }^{81}$. Cuanta más gente logras atemorizar, más importante te haces al combinar el miedo sin precedentes y la intimidación con el asesinato indiscriminado. Los suicidas son una mezcla de la batalla de Karbala y de la televisión por cable, viejos mitos y nuevos medios se dan la mano. La cultura del martirio es el substrato social en el que se alimenta el suicida bomba, es la fuente en la que bebe, es la negación total del mundo en sentido nihilista. Pero este activista no se autoinmola de forma defensiva como ocurría en el caso de los cristianos frente al Imperio romano, sino que arremete violentamente contra un enemigo al que previamente ha demonizado. Estos atacantes y sus defensores - bien considerando grande a Dios (siguiendo el ejemplo de Bin Laden) o bien considerándolo muerto (siguiendo a Nietzsche) — tienen sus vidas en sus manos y, por tanto, sus muertes.

En esta espiral de aniquilación frenética, lo que no puede ser aniquilado es la voluntad que los conduce a autoaniquilarse. Ser capaz de desearse a uno mismo fuera de la existencia es asemejarse a Dios; es tanto imitar a Dios como desactivarlo, ya que, como creador con sus propios derechos, el activista ha usurpado ahora la prerrogativa divina. El suicidio es la muerte de Dios. Aquél que está dispuesto a matarse se convierte en un dios, declara Kirilov en Los demonios $^{82}$ de Dostoievski. ¿Qué forma más descorazonadora de omnipotencia que autoaniquilarse para toda la eternidad? Sin embargo, tal acto conlleva un golpe de inmortalidad, ya que, irónicamente, su resultado es el opuesto. El atentado suicida es un supremo ejercicio de voluntad, es un activismo violento movido por la voluntad de poder. Este ricorso moderno tardío del señor de la violencia nos recuerda al personaje del Profesor, protagonista de El Agente Secreto, novela donde Joseph Conrad radiografía a la auténtica provocación terrorista moderna y que se expresa así: «La locura considerada aisladamente es verdaderamente aterrorizante en la medida en que no puedes aplacarla por medio de amenazas, persuasión o sobornos. Además, yo soy un hombre civilizado. Nunca soñaría dirigirte a organizar una mera carnicería, incluso si esperase los mejores resultados de ella. Pero no esperaría de una carnicería el resultado que deseo. El asesinato siempre está con nosotros. Es casi una institución. La demostración debe ser contra el aprendizaje de la ciencia. Pero no cualquier ciencia sirve. El ataque debe tener todo el sinsentido sorprendente de una blasfemia gratuita. Ya que las bombas son tus medios de expresión, sería realmente

81. A. Glucksmann, «Frente a la teleguerra», El Pais, 4 de abril de 2004. M. Ignatieff afirma que «las noticias son una narración mítica de la identidad social, formadas a partir de mercancías que se compran y se venden en el mercado internacional. El informativo nocturno puede considerarse un mercado en el que las imágenes terribles y alarmantes compiten entre sí por un espacio de noventa segundos. Existe un mercado del horror, como hay uno del trigo y de las tripas de cerdo, y existen unos especialistas en producir estas imágenes y distribuirlas» (El honor del guerrero. Guerra étnica y conciencia moderna, Madrid, 1999, p. 32).

82. F. DostoievsKI, Los demonios, Madrid, 1984. 
significativo si alguien pudiese arrojar una bomba en la matemática pura. Pero eso es imposible... ¿Qué te parece hacerlo sobre la astronomía?... Nada sería mejor. Tal atrocidad combina la mayor atención posible dirigida a la humanidad con el despliegue más alarmante de imbecilidad feroz. Yo desafío la ingenuidad de los periodistas para persuadir a su público que cualquier miembro del proletariado puede tener un agravio personal contra la astronomía. El hambre difícilmente podría servir para tal propósito. ¿Verdad? Y existen asimismo otras ventajas. Todo el mundo civilizado ha oído hablar de Greenwich. La voladura del primer meridiano está llamada a producir un alarido de horror» ${ }^{83}$. En el capítulo 4, el Profesor afirma: «Ellos [la gente] dependen de la vida [...], un hecho complejo, organizado, abierto al ataque en cualquier momento; mientras yo dependo de la muerte, que no conoce restricción y no puede ser atacada. Mi superioridad es evidente». Osama bin Laden, sin haber leído a Conrad, ha conseguido que el 11 y el 12 de septiembre de 2001 no volara ningún avión, es decir, los efectos de su acción son equiparables al hecho de haber "dinamitado» el meridiano de Greenwich. Evidentemente, ésta es una consecuencia no deseada ${ }^{84}$ del diseño ejecutor del complot terrorista, pero se manifiesta como hiperreal, puesto que tumbar las torres, más allá de ser una «herida nacional americana», que lo es sin duda alguna, es ante todo un atentado al programa cultural y político de la modernidad en cuanto tal ${ }^{85}$. Las torres representaban la modernidad arquitectónica, económica y científica, no sólo de la civilización americana, sino también de la civilización moderna, o, si se quiere, de una modernidad de las civilizaciones, algo así como el común denominador moderno presente en todas las civilizaciones. La mezcla de fanatismo fundamentalista y nanotecnología avanzada nos ha situado en un umbral de vulnerabilidad e inseguridad mayor que hace mil años. El problema para el fundamentalismo jacobino nihilista ya no es expresar la diferencia, objetivo irrenunciable de la modernidad, sino más bien imponer la diferencia con sangre. El poder del enemigo, así autodenominado, no radica en la omnipresente visibilidad de su musculatura militar, económica y científica, sino en su ubicuidad y en su invisivilidad. Con un marcado acento pesimista, Farhad Josrojavar lo expresa así: "Cuando el proyecto de constituir individuos que participan

83. J. Conrad, The Secret Agent, Londres, 1983, p. 43-44. Sobre el trasfondo nietzscheano del terrorismo actual "como dinamita del espíritu, quizás, una nihilina descubierta recientemente», ver el interesante trabajo de Navid Kermani, "A Dynamite of the Spirit», Times Literary Supplement, marzo, 29, núm. 5.165, 2002, p. 13-15. La mayor parte de los cristianos en América vieron la religiosidad de Timothy McVeigh como anticristiana, incluso como antirreligiosa, a pesar del fuerte énfasis cristiano que McVeigh hace en torno a lo que él considera su Biblia, el trabajo de Andre Macdonald, seudónimo de William Pierce, The Turner Diaries, Hillsboro, 1978.

84. Me refiero a lo que tuvo lugar a continuación del 11 de septiembre de 2001 con el mundo "parado», "sin usos horarios, al haberlos volado» en una acción combinada entre el nihilista pasivo, Bin Laden, y el nihilista activo, Atta.

85. U. BECK, "El mundo después del 11-S», El Pais, 19 de octubre de 2001, y Emilio LAMO DE EsPINOSA, "Ciudadanos de los EE UU», El País, 26 de octubre de 2001, han captado brillantemente el significado sociológico de este "protoahora en todos los sitios». 
totalmente en la modernidad aparece como algo absurdo en la experiencia cotidiana, la violencia se convierte en la única forma de autoafirmación. La neocomunidad se convierte en necrocomunidad. La exclusión de la modernidad adopta un significado religioso: la autoinmolación y la inmolación ajena (fundamentalista) se convierten en el modo de luchar contra la exclusión» ${ }^{86}$. Este nuevo tipo de terror comparece como un «sentimiento angustioso surgido de la combinación, inesperada y súbita, de lo sublime y lo siniestro» ${ }^{87}$.

Lo que le mueve es el amor a la muerte, cuanto peor, mejor, por tanto, para el hombre bomba, no hay líneas que separen actos criminales de actos de guerra, ni objetivos militares de objetivos civiles. El «nuevo agente portador de la barbarie» del terror organizado actual es un "terrorista nihilista» consumado que no se somete a un trabajo doctrinario, ni es esclavo de una filosofía o de una concepción del mundo, después de la caída del muro de Berlín, simplemente juega, actúa, como actuaba el «hombre sin atributos» de Robert Musil, que se autodefinía un activista y nihilista. Para él, el mundo es un juego de suma cero, la nada no es ahora la negación del bien — justicia, bienestar, libertad, desarrollo- que postula la democracia liberal, como secularización política del bien en sentido religioso, sino la negación del mal, que se manifiesta como la contingencia itinerante de enemigos múltiples, aleatorios, arbitrarios y cambiantes. Su juego ya no es el «juego profundo», en los términos de Clifford Geertz, del «héroe nacional» que se inmola en el nombre de Dios o de la nación o de un paraíso soñado e inalcanzable, para luego formar parte del panteón de los mártires, sino simplemente el juego por el juego. Cuando la violencia se rutiniza, el «creyente soldado» ${ }^{88}$ se convierte en "terrorista nihilista», porque el combustible que movía a aquél, la metáfora de la sangre derramada por Dios o por su versión secularizada, la patria, se sustituye por la nihilina ${ }^{89}$, por la dinamita del espíritu que opera bajo la premisa de que «mi vida es un arma» ${ }^{90}$. El «terrorista nihilista» actual ha elegido la intensidad, la eternidad inmediata. En ese doble suicidio brutalmente radical y por primera vez accesible a cualquiera, «mato luego soy» se hace presente una gran verdad injusta: «muero sin llegar a ser como consecuencia de tu ser matando». Como afirma André Glucksmann, «nueva o vieja idea, la idea no es la que dirige el baile, sino el baile el que hace danzar

86. F. JosRojaVAR, «Le quasi-individu: de la neo-communauté a la necro-communauté», en F. Dubet y M. Wiebiorka (eds.), Penser le sujet, París, 1995, p. 235-256.

87. Félix ANQue, «Terror», en: A. OrTIZ-OsÉS y P. LANCEROS, (ed.), Diccionario de la existencia, Barcelona, 2006, 572 y ss.

88. H. M. Enzensberger también ha visto esta mutación en las guerras civiles moleculares metropolitanas. Ver su trabajo: Perspectivas de la guerra civil, Barcelona, 2001, p. 20.

89. El primer tratamiento de la violencia nihilista moderna se lo debemos a J. CONRAD, The Secret Agent, Londres, 1983 (1906), p. 43-44. Sobre el trasfondo nietzscheano del terrorismo actual "como dinamita del espíritu, quizás, una nihilina descubierta recientemente», ver el interesante trabajo de Navid Kermani: «A Dynamite of the Spirit», Times Literary Supplement, marzo, 29, núm. 5.165, 2002, p. 13-15.

90. C. Reuter, Mein Leben ist eine Waffe, Munich, 2002. 
las ideas, ya dance un campesino iletrado, un noble letrado, un monje soldado o un libertino» ${ }^{91}$. Este "nihilismo ya no lleva los colores oscuros wagnerianos, spenglerianos y tifosos de final de siglo. Ya no surge de una Weltanschaung de decadencia ni de radicalidad metafísica nacida de la muerte de dios y de todas las consecuencias que se deben aceptar tras esa muerte. El nihilismo de hoy es transparente» ${ }^{92}$, es un nihilismo activista que se alimenta del mero «vivir hipotéticamente». El nihilismo activo interviene, revoluciona, saliéndose del modo de vivir anterior e infundiendo al que quiere morir con mayor razón el deseo del final ${ }^{93}$. El nuevo enemigo es invisible - nunca se había vuelto tan verdadera la expresión de que «uno nunca sabe realmente quien es el enemigo»— y ubicuo, "es un enemigo indefinido cuya base (el nombre árabe de $\mathrm{Al}$ Qaeda) se desplaza fácilmente de un país a otro y cuyo lugar es precisamente una ausencia de lugar» ${ }^{94}$, está aquí y allá, franquea toda frontera nacional, lucha en Afganistán, en Bosnia, en Irak, en España, en Londres, en Bali, en Estados Unidos y pretende destruir no tanto al enemigo, enormemente diverso e itinerante, como a su modo de vida. Este nuevo modelo de terror de masas se presenta como «the power of the powerless» y su estrategia de lucha pretende hacer imposible la vida de los civiles ${ }^{95}$ «enemigos» desarmados, de forma deliberadamente desmesurada, macabra y tan insoportable, que acaben rindiéndose a pesar de poseer un poder militar infinitamente superior, a diferencia de la táctica terrorista clásica de grupos como el IRA o ETA o el GIA argelino, que, al menos originariamente, consistía en desafiar el monopolio de la violencia legítima del Estado atentando contra sus aparatos: fuerzas de seguridad, jueces, incluso políticos. La violencia indiscriminada en sí misma es un símbolo, una afirmación de poder. Lo realmente problemático en relación con el estado encubierto del terrorismo transnacional es su creciente subordinación al progreso ${ }^{96}$ científico-técnico, que en sí mismo no tiene autor y depende del desarrollo de sus propios medios y plataformas audiovisuales. «El anonimato de todos aquéllos que iniciaron el ataque suicida (del 11-09-2001) meramente señala, para todos, el surgimiento de un estado encubierto global — de la cantidad desconocida de una criminalidad privada-, que "más allá del bien y del mal", durante siglos ha sido el sueño de los más cualificados sacerdotes de un progreso iconoclasta» ${ }^{97}$.

Este suicida bomba, como ricorso reencarnado de una larga tradición de mártires, no es el único que busca adhesión. En una sociedad moderna carac-

91. A. GluCKSMann, Dostoievski en Manhattan, Madrid, 2002, p. 145.

92. J. BAudrillard, Simulacra and Simulation, Ann Arbor, Michigan, 1994, p. 159.

93. M. Heidegger, Nietzsche II, Barcelona, 2000, p. 227.

94. J. GoYTisolo, «De vuelta a la razón», El País, 18 de marzo de 2004, p. 15.

95. M. KALDOR, «El terrorismo como globalización regresiva», Claves de la Razón Práctica, núm. 138, diciembre de 2003, p. 39.

96. P. Virilio, Ground Zero, Londres, 2002, p. 68.

97. P. Virilio, op. cit., p. 82. 
terizada por la diferenciación funcional de dominios sociales y por la especialización de roles, la celebridad de la persona se manifiesta de forma plural: ídolos cinematográficos, héroes deportivos, gurus mediáticos, líderes políticos, científicos renombrados, estrellas del rock y autores literarios del circuito televisivo compiten en la esfera pública por conseguir nuestras adhesiones. En una sociedad politeísta ${ }^{98}$ en el ámbito de los valores y democrática en el ámbito de la participación política, no es Dios el que elige, cuida y castiga a su pueblo, sino el individuo el que elige a su «dios» para venerarlo, porque, como apuntó Max Weber: "Cada uno sólo puede decidir por sí mismo "qué es para él Dios y qué es para él el diablo [...] cada uno elige, dentro de ciertos límites, su propio destino: el sentido de su hacer y de su ser» ${ }^{99}$ y si esto es así, tendría razón Dostoievski en la sección de «El gran inquisidor» de Los hermanos Karamazov cuando afirma que: «no existe para el hombre ansia más atormentadora que encontrar a un ser a quien venerar, ejerciendo su libertad de elección» ${ }^{100}$. El factor decisivo de la celebridad es la notoriedad, la abundancia de sus imágenes y la frecuencia con que sus nombres son mencionados en la difusión pública y en las conversaciones privadas que les siguen y persiguen. Las celebridades están en boca de todos. Como los mártires y los héroes, ellos y ellas proporcionan algo así como un pegamento que mantiene unidos lo que de otra manera serían difusos y esparcidos agregados de gente, conforman no sólo comunidades imaginadas al estilo de las mencionadas por Anderson, sino que al mismo tiempo conforman comunidades imaginarias, volátiles, de pura apariencia, efímeras, por cuanto sometidas a la enorme presión de la velocidad de cambio que afecta a todos los órdenes de la vida.

El showman P. T. Barnum ${ }^{101}$ creó el primer estadio de la cultura de la celebridad moderna al abrir el telón del entretenimiento de masas a mediados del siglo XIX con la creación del show General Tom Thumb en 1841, en donde se concitaba la presencia de máquinas de música, ventrílocuos, estatuas vivas, gitanos, gigantes, enanos, albinos, indios americanos. Los héroes de la era revolucionaria fueron invocados para dar a la nación un sentido de legitimidad histórica. Por encima de otros, George Washington representó la primera gran expresión de la virtud nacional, el símbolo del valor esencial nacional. Los héroes de esta era fueron caballeros, intelectuales y patriotas - representantes, en definitiva, de instituciones sociales básicas como el Estado, el Ejército o la Iglesia- y sus vidas aparecen como ejemplos ilustrativos. El historiador literario R. W. B. Lewis ha apuntado que la imagen heroica inventada entre 1820 y 1860 fue la de un "Adán americano» ${ }^{102}$, una figura de inocencia y promesa que, como la definió Emerson, era «el sujeto genuino contra todo el

98. Ver mi trabajo: La lucha de los dioses en la modernidad, Barcelona, 2000.

99. M. WeBER, Ensayos de metodología sociológica, Buenos Aires, 1982, p. 238.

100. F. Dostolevski, Los hermanos Karamazov, México DF, 1982, p. 166.

101. A. Henderson, "From Barnum to "Bling Bling": The Changing Face of Celebrity Culture», The Hedgehog Review, primavera, 2005, núm. 7, 1, p. 37 y s.

102. R. W. B. LeWIS, The American Adam, Chicago, 1955, p. 1-10. 
mundo» ${ }^{103}$. En una época optimista sobre la cultura indígena que se hace a sí misma, los novelistas, los poetas, los ensayistas, los críticos, los historiadores y los predicadores de la nación, todos ellos hacen suyo este discurso con gusto, pretendiendo construir no sólo una narrativa nacional, sino también crear el protagonista de tal épica. El héroe adánico, liberado del pasado e incorporando tales virtudes de autoconfianza, disciplina y logro, se convertiría en la figura central en pos de la realización de esa tarea de legitimación nacional. La emergencia de la fotografía y de la cromolitografía ${ }^{104}$ en el periodo posterior a la Guerra Civil condujo a un crecimiento explosivo en las publicaciones de masas como los periódicos y los magacines, con lo que se creó todo un espacio para el desarrollo de la industria cultural ${ }^{105}$ del ocio. Así emergieron, en la década de 1890, como figuras más admiradas, Henry Ford, Thomas Alba Edison, Guglielmo Marconi, J. P. Morgan, Andrew Carnegie o John D. Rockefeller, como hombres de ciencia, ingenieros, "capitanes de industria", ídolos todos ellos de una lucha darwiniana de success/excess capitalista. La "celebridad» se convierte en una medida de éxito en una cultura preocupada por la personalidad. La segunda década del siglo XX produce las estrellas de Hollywood, donde se filmarán películas centradas en la fama y la celebridad, como Sunset Boulevard (1950), de Billy Wilder; A Face in the Crowd (1957), de Elia Kazan; Dog Day Afternoon (1975) y Network (1976), de Sydney Lumet; King of Comedy (1982), de Martin Scorsese, o Almost Famous (2000), de Cameron Crowe. Después surgirán las estrellas del deporte y las estrellas de la música que inundan ahora toda la cultura de masas como sociedad del espectáculo ${ }^{106}$. La cultura de la celebridad tan fuertemente vinculada al consumo, puede ser criticada, asimismo, por la importancia que atribuye al elemento adquisitivo, sin embargo, no debe ser confundida con el individualismo ${ }^{107}$. A la cultura de la celebridad le falta la "espontaneidad individual» ${ }^{108}$ que J. S. Mill considera esencial para la libertad y le sobra su dependencia con estilos de vida estandarizados dentro de la sociedad de masas.

\section{A modo de conclusión}

A lo largo de estas páginas, hemos analizado la metamorfosis recurrente de arquetipos sociales que encarnan dolorosamente a la presencia de la violencia

103. R. W. B. LEWIS, op. cit., VI.

104. Tiene gran interés en el estudio de este fenómeno la obra de D. Boorstin, The Image. A Guide to Pseudoevents in America, Nueva York, 1971, p. 57.

105. Sobre el concepto de «industria cultural» siempre es una referencia obligada el trabajo de Adorno y Horkheimer del mismo título incluido en la Dialéctica de la ilustración, Madrid, 1992.

106. Interesante al respecto el trabajo de título homónimo de Guy Debord: Society of Spectacle, Detroit, 1983.

107. Sobre la celebridad, el consumo y el individualismo, ver el trabajo de W. KAMINER, «Get a Life. The Illusions of Selfinvention", The Hedgehog Review, primavera de 2005, núm. 7, 1, p. 57.

108. J. S. Mill, On Liberty, Middlesex, 1985, p. 125. 
dentro de la sociedad. Desde el chivo expiatorio mártir, pasando por el héroe nacional hasta llegar al suicida bomba, se despliega una cultura sacrificial en donde cambian las causas, los medios y los fines, pero en donde persiste un juego profundo entre la vida y la muerte aderezado de penetrantes rituales sacrificiales que sólo son contrapesados por el despliegue de contrafiguras como las de Jesús de Nazareth, el ciudadano que surge de las revoluciones liberales y burguesas y esa cultura de la celebridad propia de la sociedad de masas. Nuestro interés en este trabajo no es tanto proponer la solución definitiva que conduzca a la real y definitiva erradicación de la violencia, sino más bien despejar las conexiones de significado que subyacen a tan importantes fenómenos sociales. 